九州大学学術情報リポジトリ

Kyushu University Institutional Repository

\title{
Seedling Selection and Micropropagation for the Breeding of Yellow-Flowered Cyclamen Cultivars
}

Takamura, Takejiro

Laboratory of Horticultural Science, Faculty of Agriculture, Kyushu University

Miyajima, Ikuo

Laboratory of Horticultural Science, Faculty of Agriculture, Kyushu University

Maehara, Toshiya

Laboratory of Horticultural Science, Faculty of Agriculture, Kyushu University

https://doi.org/10.5109/24018

出版情報：九州大学大学院農学研究院紀要. 37 (3/4)，pp. 265-271，1993-03. Kyushu University バージョン：

権利関係 : 


\title{
Seedling Selection and Micropropagation for the Breeding of Y ellow-Flowered Cyclamen Cultivars
}

\author{
Takejiro Takamura, Ikuo Miyajima and Toshiya Maehara \\ Laboratory of Horticultural Science, Faculty of Agriculture, \\ Kyushu University 46-01, Fukuoka 812, Japan
}

(Received November 15, 1992)

\begin{abstract}
Pigment correlations between petals and several vegetative tissues in white- and yellow-flowered cyclamen (Cyclamen persicum) were investigated to facilitate recurrent selection of seedlings which were predicted yellow flower for breeding of superior yellowflowered cyclamen cultivars. The vegetative tissues such as leaves, leaf petioles and cotyledons of yellow-flowered cyclamen showed yellowish-green and contained the same yellow pigment as their petals, whereas those showed deep-green in white-flowered cyclamen in which the yellow pigment was not detected. The most suitable conditions for micropropagation using seedlings in vitro were also investigated. Tuber explants gave the highest shoot formation with the $10^{-6} \mathrm{M} B A\left(\mathrm{~N}^{6}\right.$-benzyladenin).
\end{abstract}

\section{INTRODUCTION}

Yellow-flowered cyclamen which was found in an inbred population of a diploid, white-flowered cultivar 'Pure White' contained chalcone as a main agent of yellow flower color (Miyajima et al., 1991). It is expected to be useful as a material for the breeding of new flower color in cyclamen.

However, obtaining of superior yellow-flowered cyclamen cultivars to the present cultivar is a long-term process. At least 2 years are required from crossing to anthesis in cyclamen. Yellow color in $\mathrm{F}_{1}$ hybrids will not be expected because yellowflowered plant seems, to be a recessive mutant which lacks chalcone-flavanone isomerase.

Therefore, rapid detection of seedlings which are predicted yellow flower is desired to facilitate recurrent selection.

In yellow-flowered cyclamen mutant, the appearance of yellow color is not limited to petals but also slightly to the leaves and leaf petioles.

The first objective of this study was to determine whether a correlation exists between the pigments in the petals and vegetative tissues, including leaves, leaf petioles of mother plants and cotyledons of seedlings by investigating the pigment profiles of them.

Reports on in vitro multiplication of cyclamen are available (Okumoto and Takabayashi, 1969; Loewenberg, 1969; Geier, 1977; Geier et al., 1979; Wainwright and Harwood, 1985; Ohashi et al., 1987, 1989; Ohashi, 1988). The commercial micropropagation of cyclamen, however, have not yet established because of erratic organogenetic potential (Geier et al., 1979). 
Wainwright and Harwood (1985) reported the advantage of micropropagation with juvenile tissues in cyclamen because of their potentially higher frequency of organogenesis.

The second objective of this study was establishment of micropropagation method using seedlings in vitro.

\section{MATERIALS AND METHODS}

\section{Pigment Analysis}

Lyophilized petals, leaves, and leaf petioles of matured plants and cotyledons of seedlings (75 days after sowing) of yellow-flowered cyclamen and white-flowered 'Pure White' were homogenized in $80 \%$ ethanol and the homogenate was filtered. The filtrates were evaporated to almost dryness under reduced pressure at $35^{\circ} \mathrm{C}$ and washed repeatedly with petroleum ether to remove the ether-soluble impurities. The concentrated residual extracts were dissolved in small amounts of distilled water, and held on Sep-Pak cartridge $\left(\mathrm{C}_{18}\right.$, Waters). The flavonoid pigments, on the cartridge were washed with distilled water to eliminate the water soluble, hydrophilic contaminants and eluted with small amounts of ethanol. The filtered ethanol eluates were then injected to high performance liquid chromatography (HPLC), in which chromatograms were developed with LC-6A pump (Shimadzu Co. Ltd.) equipped with $4.6 \mathrm{~mm} \mathrm{I.} \mathrm{D.} \mathrm{X}$ $250 \mathrm{~mm}$ Cosmosil $5 \mathrm{C}_{18}$ column (Nakarai Tesque Co. Ltd.) and a SPD-6AV detector (Shimadzu Co. Ltd.) set at $370 \mathrm{~nm}$. A flow rate of $1.0 \mathrm{ml} / \mathrm{min}$ was maintained and a mixture of acetonitrile-0.1 M acetic acid (25:75, v/v) was employed as the eluent.

\section{Seedling Culture Procedure}

The $\mathrm{F}_{2}$ seeds obtained from the crossing between 'Pure White' and yellow-flowered cyclamen were soaked in sodium hypochlorite solution ( $2 \%$ available chlorine) for $10 \mathrm{~min}$ and rinsed 3 times with sterile distilled water. The disinfected seeds were sown on 1/3 strength MS(Murashige and Skoog, 1962) medium supplemented with 30 $\mathrm{g} / l$ sucrose and solidified with $0.3 \%$ gelright. They were incubated at $20^{\circ} \mathrm{C}$ under the dark condition for 21 days followed by $12 \mathrm{~h}$ daylength for 21 days.

Young seedlings of which cotyledons, leaf petioles and tubers showed yellowish green color were selected and divided into cotyledons, leaf petioles, tubers and roots after 42 days incubation. The cotyledons, leaf petioles and tubers were divided into 5,4 , and 8 segments, respectively, and the roots were cut into 5 to $8 \mathrm{~mm}$ length and cultured.

$1 / 3$ MS medium (30 g/Z sucrose, $0.3 \%$ gelright, $\mathrm{pH}$ 5.8) containing the various combinations of NAA (1-naphthaleneacetic acid) and BA. Number of adventitious shoots were recorded after 60 days of culture and transferred to the medium containing NAA for rooting.

Calli which were formed during the culture were cut in 8 pieces and cultured under the same condition after the removal of the adventitious shoots. Number of shoots were counted after 40 days as the second culture.

Cultures were maintained at $20^{\circ} \mathrm{C}$ throughout and done under dark condition for the first 35 days followed by $16 \mathrm{~h}$ daylength. 


\section{RESULTS AND DISCUSSION}

\section{Seedling selection for the breeding of yellow-flowered cyclamen cultivars}

Leaves and leaf petioles of yellow-flowered cyclamen plants showed yellowishgreen, whereas those of 'Pure White' showed deep-green. Particularly, the reverse side of the leaves showed yellowish-green in the former plants, whereas those of the latter showed red color by anthocyanin pigment. Young seedlings which had yellowish-green leaves were easily distinguished from deep-green seedlings in $F_{2}$ offspring.

In a previous report (Miyajima et al., 1991), we identified that the main agent of the yellow color of yellow-flowered cyclamen mutant was chalcononaringenin 2'glucoside which was also a main yellow pigment in yellow - flowered carnation (Harborne, 1967, Yamaguchi, 1989) and yellow-flowered mutant in wild Callistephus chinensis (Khunet al., 1978). As shown in Fig. 1, it was not detected in the leaves, leaf petioles, and cotyledons of white-flowered cyclamen 'Pure White', as well as in the petals. On the other hand, these same vegetative tissues of yellow-flowered cyclamen and the petals contained the same pigment.

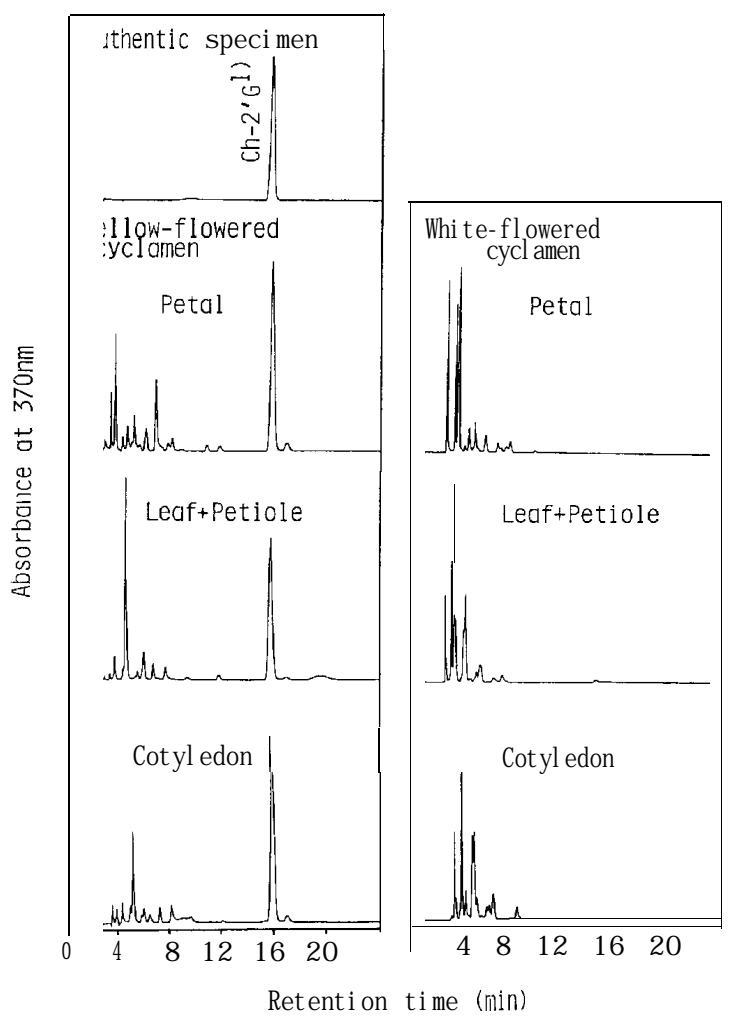

Fig. 1. HPLC profiles of pigment constitutions extracted from various organs in yellow- and white-flowered cyclamen.

${ }^{1)}$ Chalcononaringenin 2'-glucoside. 
In general, it is said that the pigments that were contained leaves and stems are closely related to the flower pigments (Ishikura, 1980). Goldy et al. (1987a, b) investigated that the pigment correlations between fruits and vegetative tissue in Muscadine grape and established the method of seedling selection. Harborne (1984) mentioned that the yellow-flowered plants which have chalcone as a main pigment in flowers occasionally contained same pigment in the vegetative tissues.

It is, therefore, suggested that the yellowish-green color of various organs in yellow-flowered cyclamen is related to the presence of chalcone. It was also confirmed from the preliminary observations that the yellowish-green seedlings flowered yellow flowers after grown up.

It seems that the seedling selection of yellow-flowered cyclamen is possible and useful for the breeding of yellow-flowered cyclamen cultivars.

\section{Micropropagation of selected cyclamen seedlings}

Adventitious shoots differentiation was observed from the calli which were formed from all the explants except roots. Explants from cotyledons and leaf petioles showed the highest shoot numbers with the $10^{-7} \mathrm{M}$ NAA and $10^{-6} \mathrm{M}$ BA and those

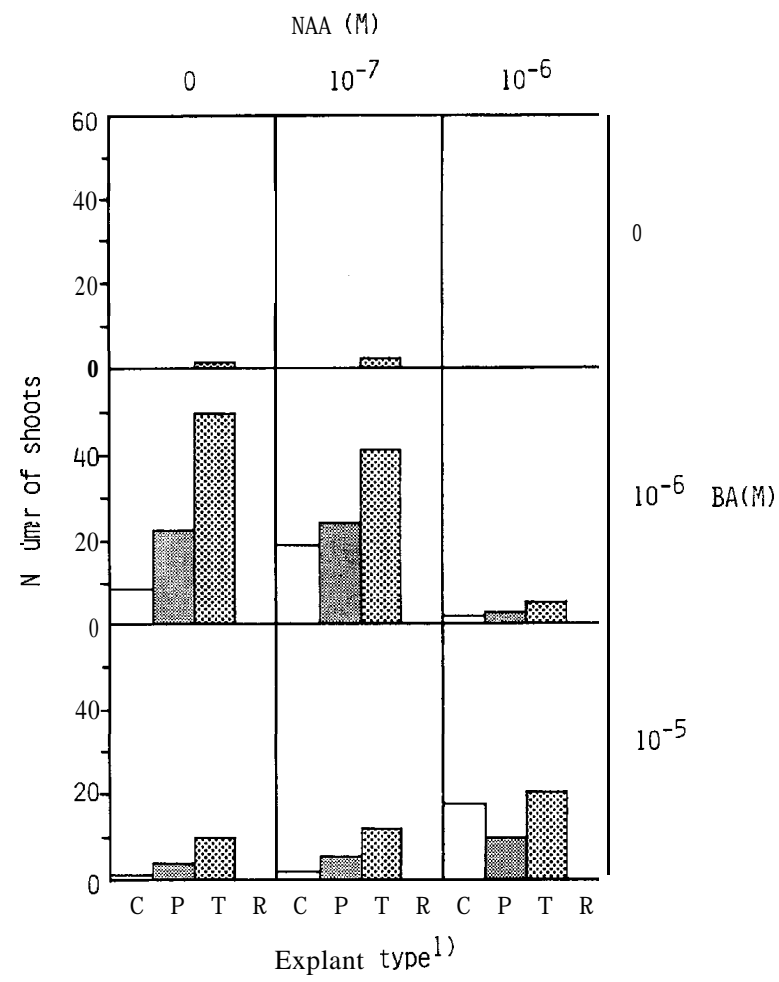

Fig. 2. Number of shoots per mother stock when cultured on 9 different media for 60 days.

${ }^{1)} \mathrm{C}$, cotyledon ; $\mathrm{P}$, petiole ; $\mathrm{T}$, tuber ; R, root 
Table 1. Percentage of explant forming shoots and number of shoots per mother stock in primary and second" culture.

\begin{tabular}{|c|c|c|c|c|c|c|}
\hline \multirow[b]{2}{*}{ Explant } & \multirow[b]{2}{*}{ type } & \multicolumn{2}{|c|}{$\begin{array}{l}\text { Conc. of plant } \\
\text { growth regulator }(\mathrm{M})\end{array}$} & \multirow{2}{*}{$\begin{array}{l}\text { Percentage of } \\
\text { explant forming } \\
\text { shoots }\end{array}$} & \multirow{2}{*}{$\begin{array}{l}\text { Number of shoots } \\
\text { per explant }\end{array}$} & \multirow{2}{*}{$\begin{array}{l}\text { Number of shoot } \\
\text { per mother stock }\end{array}$} \\
\hline & & NAA & BA & & & \\
\hline \multirow[t]{2}{*}{ Cotyledon } & primary & $10^{-7}$ & $10^{-6}$ & 70.0 & 3.80 & 19.0 \\
\hline & second & $10^{-7}$ & $10^{-6}$ & 55.6 & 1.78 & 71.1 \\
\hline \multirow[t]{2}{*}{ Petiole } & primary & $10^{-7}$ & $10^{-6}$ & 93.8 & 6.00 & 24.0 \\
\hline & second & $10^{-7}$ & $10^{-6}$ & 87.5 & 5.71 & 182.7 \\
\hline \multirow[t]{3}{*}{ Tuber } & primary & 0 & $10^{-6}$ & 90.6 & 6.25 & 50.0 \\
\hline & second & 0 & $10^{-6}$ & 72.5 & 6.28 & 401.6 \\
\hline & second & $10^{-7}$ & $10^{-6}$ & 93.8 & 6.84 & 437.8 \\
\hline
\end{tabular}

"Explants were taken from the callus of primary explants.

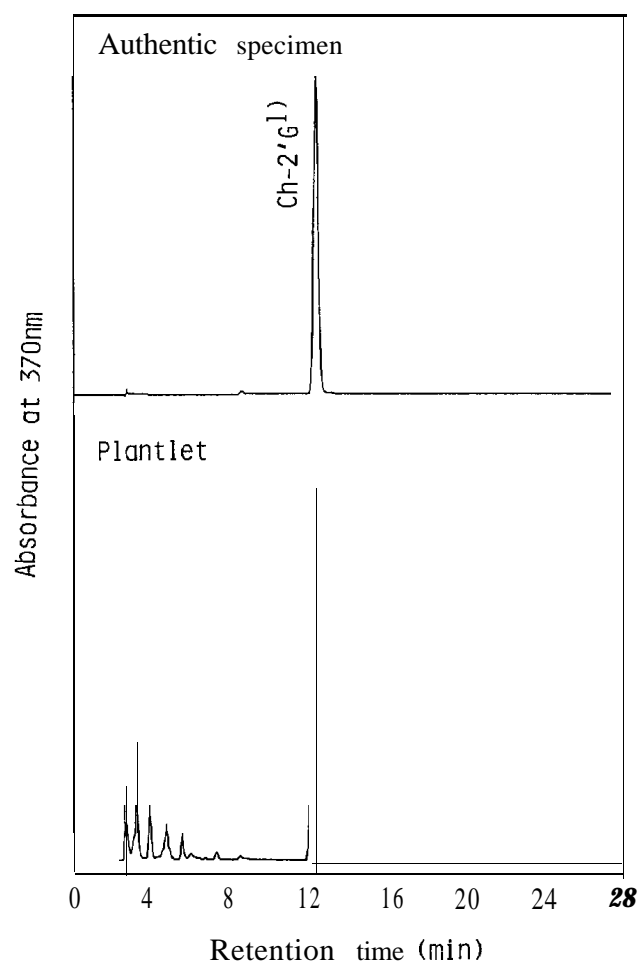

Fig. 3. HPLC profiles of pigment constitutions extracted from plantlet through tissue culture.

'Chalcononaringenin 2'-glucoside. 
from tubers showed the highest shoot formation with the $10^{-6} \mathrm{M}$ BA (Fig. 2).

Adventitious shoots developed again from the calli formed on all the explants cultured on the medium where the highest shoot formation was obtained in the first culture, although the percentage of shoot formation decreased slightly in the second culture (Table 1). The explants from the tubers formed the highest number of shoots in both the first and second culture as compared with those from the other organs.

Regenerated plantlets from the adventitious shoots showed yellowish-green color on their young leaves and they contained the same chalcone pigments as their mother plants (Fig. 3).

Wainwright and Harwood (1985) reported that the seedling tissue is suitable for the in vitro multiplication of cyclamen, in order to eliminate microbial contamination and to obtain genetical uniform plants. Also in our experiments, there were few frequency of contaminations from mother stock and it seems to be able to obtain genetically uniform progenies.

Ohashi (1988) established the method of regenerational cycle using tubers from in vitro disinfected cyclamen seedling and assumed to be able to obtain about 19,000 plants under the five times regeneration cycles. In the present report, although we could not make clear the maximum number of plantlets which were obtained under regenerational culture cycle, at least hundreds of plantlets could be obtained from one seedling in two cycles.

From the results of this study, it is suggested that the utilization of seedling selection and the method of micropropagation in selected seedlings are available in the breeding for the superior yellow-flowered cyclamen cultivars by using this yellowflowered strain.

\section{REFERENCES}

Geier, T. 1977 Morphogenesis and plant regeneration from cultured organ fragments of Cyclamen persicum. Acta Horticulturae, 76: 167-174

Geier, T., H. W. Kohlenbach and G. Reuther 1979 Clonal propagation of Cyclamen persicum by tissue culture. Gartenbauwissenschaft, 44: 226-237

Goldy, R. G., W. E. Ballinger and E. P. Maness 1987a Anthocyanin content of fruit, stem tendril, leaf, and leaf petioles in Muscadine grape. J. Amer. Soc. Hort. Sci., 112(5): 880-882

Goldy, R. G., W. E. Ballinger and E. P. Maness 1987b Pigment correlations between fruit and vegetative tissue in 10 selections of Muscadine grape. J. Amer. Soc.Hort. Sci., 112(5): 883-885

Harborne, J. B. 1967 Comparative biochemistry of the flavonoids. Academic Press, London and New York, pp. 79

Harborne, J. B. 1984 Phytochemical methods, 2nd ed. Chapman and Hall, New York. pp. 56

Ishikura, N. 1980 Plant pigments. ed. K. Hayashi, Yokendo, Tokyo. pp. 301 (In Japanese)

Khun, B., G. Forkman and W. Seyffert 1978 Genetic control of chalcone-flavanone isomerase activity in Callistephus chinensis. Planta, 138: 199-203

Loewenberg, J. R. 1969 Cyclamen callus culture. Canadian Journal of Botany, 47: 2065-2067

Miyajima, I., T. Maehara, T. Kage and K. Fujieda 1991 Identification of the main agent causing yellow color of yellow-flowered cyclamen mutant. J. Japan. Soc.Hort. Sci., 60(3): 409-414

Murashige, T. and F. Skoog 1962 A revised medium for rapid growth and bioassays with tobacco tissue cultures. Physiologia plantarum, 15: 473-479

Ohashi, K., M. Tsuchizawa, N. Minegishi and S. Yonai 1987 Propagation of Cyclamen. 1987. 
Abstr. Japan. Soc. Hort. Sci. Spring M eet.: 420-421 (In Japanese)

Ohashi, K. 1988 Propagation of Cyclamen by tissue culture. 2. Investigation of multiplication using tubers of disinfected seedlings. 1988. A bstr. Japan. Soc. Hort. Sci. Spring M eet.: 398-399 (In Japanese)

Ohashi, K., N. Minegishi and S. Yonai 1989 Propagation of Cyclamen by tissue culture. 3. Growing characterization of plants propagated by tissue culture. Jour. Japan. Soc. Hort. Sci. 58(Suppl. 1).: 434-435 (In Japanese)

Okumoto, H. and S. Takabayashi 1969 Aseptic culture of cyclamen tuber tissue. J. Japan. Soc. Hort. Sci., 38(2): 178-187

Wainwright, H. and A. C. Harwood 1985 In vitro organogenesis and plant regeneration of Cyclamen persicum Mill. using seedling tissue. Journal of Horticultural Science, 60(3): 397-403

Yamaguchi, M. 1989 Basic studies on the flower color breeding of carnations (Dianthus caryophyllus L.). Bul.Fac. Hort.Minamikyushu Univ., 19: 15-16 (In Japanese) 